\title{
ОХОТА НА КУЛИКОВ НА КАМЧАТКЕ И ЕЕ ВЛИЯНИЕ НА ПОПУЛЯЦИИ ВИДОВ, ВНЕСЕННЫХ В КРАСНУЮ КНИГУ РОССИИ
}

\author{
Клоков К. Б. ${ }^{1,2}$, Герасимов Ю. Н. ${ }^{3}$, Сыроечковский Е. Е. ${ }^{4}$ \\ ${ }^{1}$ Санкт-Петербургский государственный университет, г. Санкт-Петербург \\ ${ }^{2}$ Музей антропологии и этнографии им. Петра Великого (Кунсткамера) РАН, г. Санкт-Петербург \\ E-mail: k.b.klokov@gmail.com \\ ${ }^{3}$ Камчатский филиал Тихоокеанского института географии ДВО РАН, \\ 2. Петропавловск-Камчатский \\ E-mail: bird62@rambler.ru \\ ${ }^{4}$ Всероссийский научно-исследовательский институт охраны природы, г. Москва \\ E-mail: ees_jr@yahoo.co.uk
}

\begin{abstract}
Первое на территории России масштабное исследование по влиянию охоты на популяции куликов выполнено на Камчатке в 2019 г. Основным методом исследований был анонимный опрос охотников. В Камчатском крае принимают участие в охоте на куликов около 3.4 тыс. охотников. Из 402 охотников, участвовавших в анонимном опросе, 55 \% добывали в сезон опроса средних кроншнепов Numenius phaeopus, $9 \%$ - крупных и средних куликов других видов, $14 \%$ - мелких куликов. Всего на Камчатке по расчетам ежегодно отстреливают около 45 тыс. куликов, из них 37 тыс. составляют средние кроншнепы, 1.6 тыс. - крупные и средние кулики других видов, а также 6 тыс. мелких куликов. Из видов, внесенных в Красную книгу РФ, добывают до 20 куликов-сорок, 100 дальневосточных кроншнепов, 200 малых веретенников, 300 больших песочников и 100 исландских песочников. Охота на мелких куликов не пользуется популярностью, однако с учетом стрельбы по стаям и большого числа подранков она является причиной гибели до 12 тыс. птиц этой размерной группы, среди которых единично попадаются и кулики-лопатни. Для сохранения популяций куликов, включенных в Красные книги РФ и Камчатского края, крайне необходима специальная образовательная деятельность для охотников и инспекторов, в первую очередь - издание специального полевого определителя куликов Дальнего Востока. Также необходимо восстановление заказника «Река Морошечная», ликвидированного в 2009 г. Этот заказник включен в официальный список угодий РФ, имеющих международное значение для куликов в периоды сезонных миграций.
\end{abstract}

Ключевые слова: Камчатка, Красная книга, кулики, охота, биологические ресурсы, сохранение популяций.

DOI: 10.34078/1814-0998-2021-4-81-88

\section{ВВЕДЕНИЕ}

Ежегодно 50 млн куликов совершают сезонные перелеты из районов зимовок в ЮгоВосточной Азии и Австралии к местам размножения в России, Китае, Монголии, Японии, на Корейском полуострове и на Аляске. Совокупность этих миграционных маршрутов через 22 страны известна под названием ВосточноазиатскоАвстралазийский путь пролета (East AsianAustralasian Flyway - EAAF). Он наиболее богат видовым разнообразием из 9 основных различаемых в мире путей пролета водно-болотных птиц. Кроме того, он имеет самую высокую долю

(C) Клоков К. Б., Герасимов Ю. Н., Сыроечковский E. E., 2021 сокращающихся в численности популяций околоводных птиц. Из 63 популяций 52 перелетных вида околоводных птиц, использующих этот путь пролета, 20 популяций 17 видов могут вымереть или приблизиться к вымиранию в ближайшем будущем, если не будут приняты препятствующие этому меры (Bamford et al., 2008; Conklin et al., 2014; Pearce-Higgins et al., 2017).

В последние 30 лет эта проблема привлекла внимание многих орнитологов и экологов. Основной причиной уменьшения численности популяций куликов стало сокращение основных местообитаний: прибрежных и внутриматериковых водно-болотных угодий (Melville et al., 2016; Studds et al., 2017). Охота также воспринимается как угроза среднего или большого значения для 
популяций птиц, однако оценить ее масштабы мешает слабая изученность вопроса (Naves et al., 2019; Gallo-Cajiao et al., 2020).

Российский сегмент ЕAAF - слабозаселенная территория, поэтому основная часть местообитаний остается здесь в почти неизмененном природном состоянии. Чрезмерная охота в ключевых районах концентрации куликов во время их миграции может нести реальную угрозу популяциям. Однако никто не пробовал сделать оценку этого влияния.

Основной целью нашего исследования была оценка влияния пресса легальной охоты и браконьерства на популяции куликов, внесенных в Красную книгу России. Эти же виды относятся к приоритетным для изучения и охраны на всем EAAF (Conklin et al., 2014).

\section{МАТЕРИАЛ И МЕТОДЫ}

Отдельно изучать пресс охоты, которая в данном случае является браконьерством, на виды куликов, включенных в Красную книгу, почти невозможно. Поэтому мы направили свои усилия на выявление общего числа отстреливаемых на Камчатке куликов по их размерным группам, чтобы на основе полученных данных определить в нем долю запрещенных к добыче видов. В качестве базового вида для оценки охотничьего воздействия на популяции куликов был выбран средний кроншнеп. Это обычный и очень популярный охотничий вид на территории Камчатского края.

Основным методом изучения влияния охоты, в том числе браконьерской, на численность куликов был анонимный опрос охотников. Этот метод основан на опыте оценки охоты на водоплавающих птиц в восточной части Российской Арктики. Он был разработан Е. Е. Сыроечковским, К. Б. Клоковым (2010) и использован в 19992006 гг. для оценки добычи птиц в 22 селах Чукотки и северной Якутии. Мы немного изменили этот метод для данного исследования в связи с тем, что, в отличие от водоплавающих птиц, кулики не относятся к основным объектам охоты для местного населения.

По нашей методике работа в каждом населенном пункте включала в себя два этапа. На первом проводили углубленное интервью с 2-3 охотниками в целях выявления общей картины того, как происходит охота на куликов в этом месте и насколько она важна для местных охотников. На втором этапе мы выполняли анонимное анкетирование возможно большего числа охотников.

Для сбора материала мы посетили все населенные пункты Камчатки, связанные автомобильным сообщением. Опросом не были охвачены лишь несколько населенных пунктов в центре полуострова, где у охотников нет возможности добывать куликов из-за отсутствия мест остановок в период миграции.

Дополнительно, с использованием авиационного и водного транспорта мы посетили и провели опрос в 6 населенных пунктах на севере Камчатского края. В общей сложности получены 402 анкеты, пригодные для обработки.

Количество добываемых куликов рассчитывалось отдельно для среднего кроншнепа как базового вида, для других крупных и средних куликов, значительная часть которых на Камчатке запрещена к отстрелу, и для всех мелких куликов.

Для обобщения результатов по количеству добываемых на Камчатке куликов мы разделили территорию края на 5 частей с учетом географического положения и уровня участия местных жителей в охоте: Пенжинский, Олюторский и Карагинский районы вошли в группу Северные районы; Тигильский и Соболевский - в группу Западные районы, Быстринский и Мильковский - в Центральные районы, а Усть-Большерецкий и Елизовский вместе с городами Петропавловск-Камчатский, Елизово и Вилючинск - в группу Южные районы. Усть-Камчатский район составил отдельную группу.

По каждой из 5 частей была вычислена средняя добыча анализируемых групп куликов за сезон. Затем средние значения добычи куликов каждой группы умножали на число охотников, получивших разрешение на охоту, чтобы определить общее число куликов, добываемых на Камчатке за сезон. Многочисленные дополнительные сведения, собранные нами как в год выполнения проекта, так и ранее, были использованы для оценки добычи куликов по видам. Для этого мы учитывали как результаты опроса охотников, так и собственные наблюдения авторов, в том числе результаты осмотра добычи.

Несистематизированный сбор сведений об охоте на куликов на Камчатке проводится одним из авторов этой статьи (Ю. Н. Герасимов) уже около 30 лет. Во многом он был связан с длительными полевыми работами, целью которых было изучение миграции этой группы птиц (Герасимов, Герасимов, 2014). Во время выполнения полевых работ, которые проводились, как правило, в местах интенсивной охоты, мы имели возможность общаться с охотниками, а иногда и с браконьерами, наблюдать за процессом их охоты и осматривать добычу. Весной миграция почти всех видов куликов проходит позже времени весенней охоты на водоплавающих птиц. Поэтому кулики весной добываются, как правило, только в результате браконьерской охоты после завершения ее легальной части.

Кольцевание куликов в целях выяснения их миграционных связей началось на Камчатке в 1989 г., массовое кольцевание - в 2014-2021 гг. 
Так как оно проводилось в период охоты на куликов, мы имели возможность наблюдать за этим процессом, регулярно общаться с охотниками и осматривать их добычу. Кроме того, дополнительная информация о миграции куликов и охоте на них была собрана в ходе многочисленных кратковременных (2-4 дня) посещений различных районов Камчатки, в том числе при проведении орнитологических исследований с другими целями.

\section{РЕЗУЛЬТАТЫ И ОБСУЖДЕНИЕ}

\section{Сохранение популяций}

Сохранение популяций видов птиц, представляющих интерес для охотников, зависит от двух основных условий. Это природоохранный статус вида (запрет на отстрел) и сохранение местообитаний, в том числе наличие особо охраняемых природных территорий (ООПТ) в местах концентрации птиц.

В Красную книгу РФ 2000 г. было включено 6 видов куликов, встречающихся на Камчатке (Красная книга..., 2000). В начале 2000-х гг. в России официальный статус получили региональные Красные книги. Это означало полный запрет на добычу включенных в них видов, за отстрел которых полагался штраф. В 2006 г. камчатские орнитологи включили в региональную красную книгу 6 видов (7 подвидов) куликов (Красная книга..., 2006).

В 2018 г. количество видов куликов, включенных во 2-е издание Красной книги Камчатки, было увеличено до 10. В него, дополнительно к видам, уже имеющимся в предыдущем издании, мы добавили виды, у которых наблюдалось сильное снижение численности на ВосточноазиатскоАвстралазийском пролетном пути (Conklin et al., 2014; Герасимов и др., 2018). Это большой песочник Calidris tenuirostris, исландский песочник Calidris canutus, краснозобик Calidris ferruginea и малый веретенник Limosa lapponica (Красная книга..., 2018). В 2020 г. эти 4 вида были включены и в Красную книгу РФ (Приказ Министерства природных ресурсов и экологии РФ от 24 марта 2020 г. № 162).

К настоящему времени из 38 видов куликов, встречающихся в Камчатском крае (случайно залетные виды не учтены), 10 видов внесены в Красную книгу РФ, 11 - в Красную книгу Камчатского края. Из оставшихся 27 видов куликов лишь 15 относятся к охотничьим, и они официально разрешены к отстрелу. Остальные 12 видов куликов не являются охотничьими, и формально их добыча запрещена. Однако наш многолетний опыт с охотниками и инспекторами показывает, что и те, и другие не умеют их различать, поэтому запрет является чисто формальным. К сожалению, охотники и инспектора не знают и боль- шинство видов куликов, внесенных в Красные книги РФ и Камчатского края. И эта проблема существенно усложняет вопросы, связанные с их охраной.

Что касается сохранения местообитаний, то природные территории края, включая все его побережья, до настоящего времени являются мало измененными. Добыча нефти, в том числе в шельфовой зоне, отсутствует. Какой-либо серьезной угрозы местообитаниям охотничьих птиц до настоящего времени нет. Кроме того, Камчатка в конце XX в. выгодно отличалась от многих других регионов России наличием хорошо развитой системы ООПТ, созданной в 1960-1980-е гг. и в значительной степени направленной на сохранение популяций мигрирующих водных и околоводных птиц. Наиболее важной частью этой системы были региональные заказники (Герасимов, Герасимов, 2013). Особое значение для сохранения куликов имел заказник «Река Морошечная». Устьевой лиман р. Морошечная, входящий в этот заказник, был включен Российским правительством в список Рамсарских угодий, а также в «Сеть угодий, имеющих международное значение для куликов как место остановки на Восточноазиатско-Австралазийском пути пролета» (Gerasimov, Gerasimov, 1998, 2000; Huettmann, Gerasimov, 2002; Schuckard et al., 2006).

Деградация системы региональных ООПТ Камчатки началась в конце 1990-х гг., а особенно серьезный ущерб ей был нанесен в 2000-е гг. Без подготовки каких-либо обоснований было упразднено 8 заказников, в том числе «Река Морошечная». С ликвидацией заказников все четыре Рамсарские угодья, расположенные в пределах Камчатского края, потеряли реальный охранный статус (Герасимов, Герасимов, 2013).

Охотники Камчатского края, их численность и распределение

Общее число охотников на Камчатке по последним официальным данным за 2016 г. (более поздние официальные данные отсутствуют), предоставленным нам Агентством лесного хозяйства и охраны животного мира Камчатского края, составляло 19164 чел. Это около $6 \%$ от общей численности населения края. Самый высокий процент охотников от общей численности населения был в Пенжинском - 19.8 и Быстринском - 16.0 районах. В северных районах Камчатки некоторые охотники, особенно принадлежащие к коренным малочисленным народам Севера, не регистрируются. Так что общее количество охотников на Камчатке должно быть около 20 тыс. чел. или слегка превышать эту цифру.

Для оценки числа добытых куликов необходимо знать количество охотников, участвовавших в их добыче в конкретный сезон. Для этого мы использовали информацию по числу выданных се- 
зонных разрешений (материалы предоставлены Агентством лесного хозяйства и охраны животного мира Камчатского края), из которой следовало, что на август 2018 г. разрешение на добычу куликов в Камчатском крае получили 3395 охотников.

Помимо зарегистрированных охотников, есть еще какое-то число людей, которые охотятся нелегально. Согласно нашим неофициальным интервью, их число значительно сократилось за последнее десятилетие благодаря усилению полицейского контроля за оружием. Однако незаконная охота по-прежнему ведется в больших объемах в отдаленных населенных пунктах как местными жителями, так и приезжими рыбаками, что связано с полным отсутствием там не только охотничьего, но и полицейского контроля.

Объем добычи куликов на территории Камчатского края

Все охотники Камчатки знают среднего кроншнепа, или, как его обычно называют, «ягодника». Многие знают дальневосточного кроншнепа, называя его «кроншнепом» или «большим кроншнепом». Некоторые знают веретенников, называя их «прямоклювыми ягодниками». На этом познания даже опытных охот- ников, как правило, заканчиваются. И очень редко нам встречались охотники, которые различали и некоторые другие виды, например, щеголя Tringa erythropus. На северо-западном побережье Камчатки летом формируются значительные концентрации больших песочников, местные охотники их тоже различают, иногда называя «глупышами» за их доверчивое отношение к людям. Мелкие виды куликов не различает никто, называя их все вместе «бекасиками», «пельменями», «галушками» и т. п.

Надо отметить, что охотники, проживающие на территории Камчатского края, сравнительно хорошо знают большинство, а иногда и все виды утиных птиц. Это относится даже к коренному населению малочисленных народов Севера. Поэтому мы предполагаем, что низкая способность охотников определять вид куликов объясняется тем, что кулики, особенно мелкие, не интересны им как добыча.

Согласно анонимным анкетам, использованным в 2019 г., 55 \% охотников, получивших путевки на охоту, отстреливали среднего кроншнепа. Средняя добыча одного охотника по Камчатке составила 8.9 особей этого вида (табл. 1, 2).

Таблица 1. Количество опрошенных охотников и \% охотников, добывающих куликов

Table 1. Number of questionned hunters and percentage of wader hunters

\begin{tabular}{|l|c|c|c|c|c|c|}
\hline \multicolumn{1}{|c|}{ Показатель } & \multicolumn{7}{|c|}{ Районы Камчатки } \\
\cline { 2 - 8 } & Север & Запад & Восток & Центр & Юг & Всего \\
\hline Заполнено анонимных анкет & 107 & 60 & 55 & 14 & 166 & 402 \\
\hline \% охваченных опросом охотников & 39.0 & 17.0 & 11.0 & 2.0 & 5.0 & 8.0 \\
\hline $\begin{array}{l}\text { \% охотников, добывающих среднего } \\
\text { кроншнепа }\end{array}$ & 21.2 & 96.6 & 100.0 & 0 & 51.2 & 55.1 \\
\hline $\begin{array}{l}\text { \% охотников, добывающих других } \\
\text { крупных и средних куликов }\end{array}$ & 9.6 & 27.6 & 3.7 & 0 & 4.9 & 9.2 \\
\hline $\begin{array}{l}\text { \% охотников, добывающих мелких } \\
\text { куликов }\end{array}$ & 11.5 & 34.5 & 22.2 & 0 & 7.3 & 14.3 \\
\hline
\end{tabular}

Таблица 2. Оценка количества добываемых куликов

Table 2. Estimation of the harvested waders number

\begin{tabular}{|c|c|c|c|c|c|c|}
\hline \multirow{2}{*}{ Показатель } & \multicolumn{6}{|c|}{ Районы Камчатки } \\
\hline & Север & Запад & Восток & Центр & Юг & Всего \\
\hline Количество охотников & 275 & 343 & 481 & 572 & 3244 & 4915 \\
\hline \multicolumn{7}{|c|}{ Среднее число куликов, добываемых одним охотником } \\
\hline Средний кроншнеп & 2.06 & 23.21 & 15.85 & 0 & 6.45 & 8.86 \\
\hline Другие большие и средние виды & 0.52 & 1.93 & 0.04 & 0 & 0.24 & 0.53 \\
\hline Мелкие кулики & 1.62 & 10.07 & 0.44 & 0 & 0.61 & 2.23 \\
\hline \multicolumn{7}{|c|}{ Суммарное количество куликов, добываемых в течение года } \\
\hline Средний кроншнеп & 566 & 7960 & 7625 & 0 & 20928 & 37078 \\
\hline Другие большие и средние виды & 143 & 662 & 18 & 0 & 791 & 1614 \\
\hline Мелкие виды & 444 & 3454 & 214 & 0 & 1978 & 6090 \\
\hline Всего & 1153 & 12076 & 7857 & 0 & 23697 & 44782 \\
\hline
\end{tabular}


Основная часть средних кроншнепов добывается на юге - в Елизовском и Усть-Большерецком районах. Это обусловлено тем, что на юговостоке полуострова сосредоточено более $90 \%$ населения Камчатки, проживающего в городах Петропавловск-Камчатский, Елизово, Вилючинск и в окружающих их поселках.

Как показали наши расчеты, суммарное количество средних кроншнепов, добываемых в Камчатском крае за 1 сезон, составляет около 37 тыс. особей. Это весьма значительное число, и мы считаем, что наша оценка очень близка к истине. Вместе с тем, по имеющимся опубликованным оценкам численности среднего кроншнепа на зимовках Восточноазиатско-Австралазийского пролетного пути, к которому относится и Камчатка, численность этого вида составляет лишь около 55 тыс. особей (Bamford et al., 2008; Conklin et al., 2014). Мы предполагаем, что эта оценка значительно занижена.

По данным имеющихся у нас наблюдений средних кроншнепов в местах концентраций, а также на основе другой информации, мы оценивали минимальную численность этого вида на Камчатке в период летне-осенней миграции в 80-100 тыс. особей (Герасимов, Герасимов, 2014). Наблюдения последних лет позволяют предположить, что более реалистичная оценка численности средних кроншнепов на Камчатке во время миграции на юг составляет 120-150 тыс. особей.

Расчеты численности других как охраняемых, так и неохотничьих видов куликов Камчатки в период летне-осенней миграции приведены в табл. 3. Они сделаны на основе как опубликованных (Кривенко и др., 2019), так и неопубликованных данных.

В представленном исследовании нас во многом интересовала добыча видов, внесенных в
Красные книги РФ и Камчатского края. Благодаря анонимному анкетированию и прямому опросу охотников, а также осмотру добычи, который мы в прошлые годы имели возможность проводить, мы смогли сделать приблизительные оценки их количества. Из-за отсутствия официальных математических расчетов этой добычи мы склонны считать их экспертными.

По данным анонимного анкетирования, в 2019 г. $9.2 \%$ охотников Камчатки, кроме среднего кроншнепа, добывали и других куликов крупного и среднего размера. В среднем по 0.5 птицы на одного охотника в год, а в сумме около 1600 особей. В среднем на каждые 22 средних кроншнепа был добыт 1 кулик другого вида крупного или среднего размера. Мы знаем приблизительную численность куликов на Камчатке в период летне-осенней миграции, их места концентрации и доступность для охотников (Герасимов, Герасимов, 2014; Кривенко и др., 2019). Также мы неоднократно имели возможность осматривать добытых птиц. Все это позволило нам сделать приблизительную оценку добываемых запрещенных к отстрелу и охотничьих видов куликов крупного и среднего размера (табл. 3).

Кулик-сорока Haematopus ostralegus (дальневосточный подвид $H$. o. osculans) включен в Красную книгу РФ. Это крупный кулик, весенняя миграция которого проходит рано. Уже в первой декаде мая птицы занимают гнездовые участки, расположенные в основном на песчаных косах, отделяющих приустьевые лиманы рек от Охотского моря. В это время большое число охотников находится в угодьях, а куликов-сорок относительно легко добыть. Однако большинство охотников, по нашим данным, щадят этих красивых птиц, которые в мае - июле подпускают людей

Таблица 3. Численность крупных и средних видов куликов и оценка их добычи на Камчатке в период летне-осенней миграции

Table 3. Number of big and medium-size waders and estimation of harvesting them during the summer-fall migration

\begin{tabular}{|l|c|c|c|}
\hline \multicolumn{1}{|c|}{ Вид } & $\begin{array}{c}\text { Оценка численности } \\
\text { (особей) }\end{array}$ & $\begin{array}{c}\text { Оценка добычи } \\
\text { (особей) }\end{array}$ & \% изьятия \\
\hline \multicolumn{3}{|c|}{ Охраняемые виды } \\
\hline Кулик-сорока & 1000 & $10-20$ & $2.5-5.0$ \\
\hline Дальневосточный кроншнеп & 1000 & $50-100$ & $5.0-10.0$ \\
\hline Малый веретенник & 10000 & $100-200$ & $1.0-2.0$ \\
\hline Большой песочник & 60000 & $200-300$ & $3.3-5.0$ \\
\hline Исландский песочник & 4000 & $1.3-2.5$ \\
\hline \multicolumn{3}{|c|}{ Охотничьи виды } \\
\hline Бурокрылая ржанка & 2000 \\
\hline Тулес & 3000 & $50-100$ & $2.5-5.0$ \\
\hline Камнешарка & 2000 & $50-100$ & $1.7-3.3$ \\
\hline Большой веретенник & 30000 & $50-100$ & $2.5-5.0$ \\
\hline Улиты & 150000 & $300-600$ & $1.0-2.0$ \\
\hline Бекасы & 100000 & $400-500$ & $0.2-0.3$ \\
\hline
\end{tabular}


близко. Случаи браконьерства нам также известны, но они происходят относительно редко. По нашей оценке, на Камчатке добывают не более 5 \% осенней численности популяции (см. табл. 3).

Дальневосточный кроншнеп Numenius madagascariensis на Камчатке в подходящих местообитаниях относительно обычен. Большинство охотников отличают его и знают, что это охраняемый вид. Нами регистрировались случаи отстрела, часть из них происходит по причине ошибки, так как у молодых начавших летать птиц клюв значительно короче, чем у взрослых, и охотники путают их со средними кроншнепами. Мы предполагаем, что за сезон добыча может достигать $10 \%$ численности популяции (см. табл. 3).

Малый веретенник в настоящее время включен в Красную книгу России, а большой веретенник продолжает оставаться охотничьим видом на Камчатке. Охотники и инспектора не различают их. В целом в период летне-осенней охоты большие веретенники встречаются значительно чаще, чем малые, особенно учитывая доступность мест концентрации для охотников. Поэтому, по нашей оценке, на одного добытого малого веретенника должно приходиться не менее 5 больших веретенников, а общая численность добываемых малых веретенников составляет 1.0-2.0 \% от численности популяции (см. табл. 3).

Большой и исландский песочники относятся к куликам средних размеров. Ни охотники, ни инспектора, как правило, не знают, что эти виды внесены в Красную книгу РФ. Есть места концентрации, где их могут добывать в период летне-осенней миграции, процент изъятия был оценен в 1.5-5.0 (см. табл. 3).

По данным наших анонимных опросов на Камчатке в 2019 г. 14.3 \% охотников отстреливали мелких куликов, в основном чернозобиков Calidris alpina, песочников-красношеек Calidris ruficollis и монгольских зуйков Charadrius mongolus, которые формируют концентрации мелких куликов на грязевых и песчаных отмелях во время миграции. Формально все эти три вида запрещены к отстрелу, так как не внесены в список охотничьих видов. Практически этот запрет совсем не соблюдается, о нем не знают ни охотники, ни большинство инспекторов. В среднем охотник Камчатского края добывает 2.2 особи мелких куликов в год, а их общая добыча, рассчитанная методом экстраполяции, превышает 6 тыс. особей. Более половины птиц было отстреляно в западных (Соболевском и Тигильском) районах, где в среднем добывается около 10 мелких куликов на охотника. В других районах охотники в среднем добывают менее 2 птиц на человека в год.

Охота на мелких куликов была гораздо более распространена на Камчатке несколько десятилетий назад. Сейчас, по мнению опрошенных охотников, ее популярность значительно снизилась.
Нас охота на мелкие виды интересовала главным образом из-за возможности отстрела куликалопатня Eurynorinchus pygmeus, одного из самых редких куликов в мире.

Сообщая о количестве добытых мелких куликов в анонимных анкетах, охотники никогда не упоминали о видах. В беседах они отмечали, что для экономии патронов при охоте на мелких птиц стреляют только по стаям. Очевидно, что при таком способе охоты остается много подранков, которые потом погибают. Мы наблюдали такую охоту и ее результаты, в том числе находили погибших от ранения птиц. Поэтому общее число погибших в результате охоты мелких куликов на Камчатке предположительно составляет 10 12 тыс. особей за сезон. Несомненно, что в это число единично попадают и кулики-лопатни, держащиеся в период миграции в одних стаях с чернозобиками и песочниками-красношейками.

\section{БЛАГОДАРНОСТИ}

Проект осуществляется Российским обществом сохранения и изучения птиц им. М. А. Мензбира (РОСИП) в сотрудничестве с Рабочей группой по куликам Северной Евразии и поддерживается несколькими фондами, в том числе Фондом Карла Кауса, EAAFP и UNEP/CMS, при участии Российского научного фонда (проект № 18-18-00309), которым мы выражаем нашу глубокую благодарность. Мы также благодарим за помощь в проведении исследований руководство и сотрудников Агентства лесного хозяйства и охраны животного мира Камчатского края, а также региональных обществ охотников.

Отдельное спасибо нашим коллегам Н. Н. Герасимову, Д. С. Дорофееву, А. П. Иванову, Е. Г. Лобкову, А. И. Мацыне, С. П. Харитонову, С. И. Вахрину за предоставленную информацию и методические советы.

\section{ЛИТЕРАТУРА}

Герасимов Н. Н., Герасимов Ю. Н. Исследования миграций водоплавающих и околоводных птиц Камчатки // Ареалы, миграции и другие перемещения диких животных : Материалы Междунар. науч.-практ. конф. (Владивосток, 25-27 нояб. 2014 г.). Владивосток : ООО «Рея», 2014. С. 52-61.

Герасимов Ю. Н., Герасимов Н. Н. Система региональных ООПТ Камчатки и ее развитие (критический взгляд) // Сохранение биоразнообразия Камчатки и прилегающих морей : доклады XII-XIII международ. науч. конф., 2011-2012 гг. ПетропавловскКамчатский : Камчатпресс, 2013. С. 22-32.

Герасимов Ю. Н., Томкович П. С., Сыроечковский Е. Е., Лаппо Е. Г. Кулики ВосточноазиатскоАвстралазийского пролетного пути с резко сокращающейся численностью нуждаются в срочных мерах охраны / Первый Всерос. орнитол. конгресс (Тверь, Россия, 29 янв. -4 февр. 2018 г.) : тез. докл. Тверь, 2018. C. 76-77. 
Красная книга Камчатки. Т. 1. Животные. Петропавловск-Камчатский : Камчатский печатный двор, 2006. 270 c.

Красная книга Камчатского края. Т. 1. Животные. Петропавловск-Камчатский : Камчатпресс, 2018. 196 с.

Красная книга Российской Федерации (животные). Москва : Астрель, 2000. 862 с.

Кривенко В. Г., Валенцев А. С., Герасимов Ю. Н., Кириченко В. Е., Кузнецов А. В., Слодкевич В. Я., Ткаченко $B$. $Г$. Охотничьи животные Камчатского края (состояние ресурсов, охрана и рациональное использование). Петропавловск-Камчатский : Камчатпресс, 2019. $238 \mathrm{c}$.

Сыроечковский Е. Е., Клоков К. Б. Использование метода анкетирования для изучения влияния охоты на водоплавающих птиц в Российской Арктике // Казарка. 2010. Т. 13. С. 76-103.

Bamford M., Watkins D., Bancroft W., Tischler G., Wahl J. Migratory shorebirds of the East Asian-Australasian Flyway: Population estimates and internationally important sites. Wetlands International - Oceania. Canberra, 2008. $240 \mathrm{p}$.

Conklin J. R., Verkuil Y. I., Smith B. R. Prioritizing migratory shorebirds for conservation action on the East Asian-Australasian Flyway. Hong Kong, 2014. 128 p.

Gallo-Cajiao E. J. W., Morrison T. H., Woodworth B. K., Lees A. C., Naves L. C., Yongg D. L., Choi C. Y., Mundkur T., Bird J., Jain A., Klokov K., Syroechkovskiy E., Chowdhury S. U., Fu V. W. K., Watson J. E. M., Fuller $R$. A. Extent and potential impact of hunting on migratory shorebirds in the Asia-Pacific // Biological Conservation. 2020. No. 246. P. 1-12.

Gerasimov N. N., Gerasimov Yu. N. The international significance of wetland habitats in lower Moroshechnaya River (West Kamchatka, Russia) for waders. International Wader Studies. 1998. Vol. 10. P. 237-242.

Gerasimov Yu. N., Gerasimov N. N. The importance of the Moroshechnaya River Estuary as a staging site for shorebirds. Stilt. 2000. No. 36. P. 20-25.
Huettmann F., Gerasimov Yu. Using sampling to obtain density estimates for Whimbrels (Numenius phaeopus) and other birds in the coastal tundra of the Moroshechnaya River Spit, Sea of Okhotsk, during fall migration // Avian Ecology and Behavior. 2002. Vol. 8. P. 49-69.

Melville D. S., Chen Y., Ma Z. Shorebirds along the Yellow Sea coast of China face an uncertain future: A review of threats // Emu. 2016. No. 116. P. 100-110.

Naves L. C., Keating J. M., Tibbitts T. L., Ruthrauff $D$. $R$. Shorebird subsistence harvest and indigenous knowledge in Alaska: Informing harvest management and engaging users in shorebird conservation // The Condor. Ornitholodgical applications. 2019. Vol. 121. P. 1-19. DOI: 10.1093/condor/duz023

Pearce-Higgins J. W., Brown D. J., Douglas D. J. T., Alves J. A., Bellio M., Bocher P., Buchanan G. M., Clay R. P., Conklin J., Crockford N., Dann P., Elts J., Friis Ch., Fuller R. A., Gill J. A., Gosbell K., Johnson J. A., Marquez-Ferrando R., Masero J. A., Melville D. S., Millington S., Minton C., Mundkur T., Nol E., Pehlak H., Piersma Th., Robin F., Rogers D. I., Ruthrauff D. R., Senner N. R., Shah J. N., Sheldon R. D., Soloviev S. A., Tomkovich P. S., Verkuil Y. I. A global threats overview for Numeniini populations: synthesizing expert knowledge for a group of declining migratory birds // Bird Conservation International. 2017. No. 27 (1). P. 6-34.

Schuckard R., Huettmann F., Gosbell K., Geale J., Kendal S., Gerasimov Yu., Matsina E., Greeves W. Shorebird and Gull Census at Moroshechnaya Estuary, Kamchatka, Far East Russia, during August 2004 // Stilt. 2006. No. 50. P. 34-46.

Studds C. E., Kendall B. E., Murray N. J., Wilson H. B., Rogers D. I., Clemens R. S., Gosbell K., Hassell C. J., Jessop R., Melville D. S., Milton D. A., Minton C. T. D., Possingham H. P., Riegen A. C., Straw P., Woehler E. J., Fuller R. A. Rapid population decline in migratory shorebirds relying on Yellow Sea tidal mudflats as stopover sites // Nature Communications. 2017. No. 8:14895. Doi:10.1038/ ncomms14895.

Поступила в редакциюю 30.09.2021 2.

Поступила после доработки 10.11.2021 2.

\title{
WADER HUNTING IN KAMCHATKA AND ITS IMPACT ON POPULATIONS OF SPECIES LISTED IN THE RED DATA BOOK OF RUSSIA K. B. Klokov ${ }^{1,2}$, Y. N. Gerasimov ${ }^{3}$ E. E. Syroechkovskiy ${ }^{4}$
}

\author{
${ }^{1}$ Saint-Petersburg State University, Saint-Petersburg \\ ${ }^{2}$ Peter the Great Museum of Anthropology and Ethnography (Kunstkamera), RAS, Saint-Petersburg \\ ${ }^{3}$ Kamchatka Branch of the Pacific Institute of Geography FEB RAS, Petropavlovsk-Kamchatsky \\ ${ }^{3}$ All-Russian Research Institute for Nature Conservation, Moscow
}

The first in Russia large-scale study on the impact of hunting on wader populations was carried out in Kamchatka in 2019. The main research method was anonymous hunters questioning. In Kamchatka Krai, about 3.400 hunters take part in the wader hunt. Of the 402 hunters, who participated in the anonymous questioning, $55 \%$ were hunting Whimbrels in the current season; $9 \%$, other large and medium-size wader species; $14 \%$, smaller waders. The total of about 45.000 waders are shot annually in Kamchatka, including 37.000 Whimbrels 1.600 waders of other large species, and 6 thousand waders of smaller species. From the species listed in the Red Data Book of the Russian Federation, up to 20 Oystercatchers, 100 Far Eastern Curlews, 200 Bar-tailed Godwits, 300 Grater 
Knots, and 100 Red Knots are shot. Hunting smaller waders is not popular, but it causes the death of up to 12.000 thousand smaller waders, with Spoon-billed Sandpiper also occasionally killed. Special educational activities for hunters and hunting officers are required for conservation of wader populations included in the Red Data Books of the Russian Federation; first, a special field guide of waders in the Far East should be published. It is also necessary to restore the Moroshechnaya River sanctuary reserve, liquidated in 2009 yet included in the official list of areas of international importance for waders on the East Asian-Australasian Flyway.

\section{Keywords: Kamchatka, Red Data Book, waders, hunting, wildlife resources, conservation of population.}

\section{REFERENCES}

Bamford, M., Watkins, D., Bancroft, W., Tischler, G., Wahl, J., 2008. Migratory Shorebirds of the East Asian-Australasian Flyway: Population Estimates and Internationally Important Sites. Wetlands International Oceania, Canberra.

Conklin, J. R., Verkuil, Y. I., Smith, B. R., 2014. Prioritizing Migratory Shorebirds for Conservation Action on the East Asian-Australasian Flyway. Hong Kong.

Gallo-Cajiao E. J. W., Morrison T. H., Woodworth, B. K., Lees, A. C., Naves, L. C., Yongg, D. L., Choi, C. Y., Mundkur, T., Bird, J., Jain, A., Klokov, K., Syroechkovskiy, E., Chowdhury, S. U., Fu, V. W. K., Watson, J. E. M., Fuller, R. A., 2020. Extent and Potential Impact of Hunting on Migratory Shorebirds in the Asia-Pacific, Biological Conservation. 246, 1-12.

Gerasimov, N. N. Gerasimov, Yu. N., 1998. The International Significance of Wetland Habitats in Lower Moroshechnaya River (West Kamchatka, Russia) for Waders, International Wader Studies. 10, 237-242.

Gerasimov, N. N., Gerasimov, Yu. N., 2014. Research of Water Fowl and Semiaquatic Birds Migrations in Kamchatka, Areals, Migrations, and Other Movements of Wild Animals, Proceedings of the International Scientific-Practical Conference, Vladivostok, November 25-27, 2014. Vladivostok. 52-61 [In Russian].

Gerasimov, Yu. N., Gerasimov, N. N., 2013. The System of Regional Protected Areas in Kamchatka and Its Development (Critical View), Conservation of Biodiversity in Kamchatka and the Adjacent Seas. Reports of the 12-13 th International Scientific Conference, 2011-2012. Petropavlovsk-Kamchatsky, Kamchatpress. 22-32 [In Russian].

Gerasimov, Yu. N., Gerasimov, N. N., 2000. The Importance of the Moroshechnaya River Estuary as a Staging Site for Shorebirds, Stilt. 36, 20-25.

Gerasimov, Y. N., Tomkovich, P. S., Syroechkovskiy, E. E., Lappo, E. G., 2018. Waders of the East Asian-Australasian Flyway with Sharply Declining Numbers Need Urgent Protection Measures, First All-Russia's Ornithological Congress (Tver, Russia, 29 January - 4 February 2018), Abstracts of Reports. Tver. 76-77 [In Russian].

Syroechkovskiy, E. E., Klokov, K. B., 2010. Using the Questionnaire Method to Study the Impact of Hunting on Waterfowl in the Russian Arctic, Kazarka. 13, 76-103 [In Russian].

The Red Data Book of Kamchatka. Vol. 1. Animals, 2006. Petropavlovsk-Kamchatsky [In Russian].
The Red Data Book of Kamchatka Krai, 2018. Vol. 1. Animals. Petropavlovsk-Kamchatsky, Kamchatpress [In Russian].

The Red Data Book of the Russian Federation (Animals), 2000. Moscow, Astrel [In Russian].

Huettmann, F., Gerasimov, Yu., 2002. Using Sampling to Obtain Density Estimates for Whimbrels (Numenius phaeopus) and Other Birds in the Coastal Tundra of the Moroshechnaya River Spit, Sea of Okhotsk, during Fall Migration, Avian Ecology and Behavior. 8, 49-69.

Krivenko, V. G., Valentsev, A. S., Gerasimov, Yu. N., Kirichenko, V. E., Kuznetsov, A. V., Sladkevich, V. Ya., Tkachenko, V. G., 2019. Hunting Animals of Kamchatka Krai (State of Resources, Protection, and Rational Use). Petropavlovsk-Kamchatsky, Kamchatpress [In Russian].

Melville, D. S., Chen, Y., Ma, Z., 2016. Shorebirds along the Yellow Sea Coast of China Face an Uncertain Future: A Review of Threats, Emu. 116, 100-110.

Naves, L. C., Keating, J. M., Tibbitts, T. L., Ruthrauff, D. R., 2019. Shorebird Subsistence Harvest and Indigenous Knowledge in Alaska: Informing Harvest Management and Engaging Users in Shorebird Conservation, The Condor. Ornitholodgical Applications. 121, 1-19.

Pearce-Higgins, J. W., Brown, D. J., Douglas, D. J. T., Alves, J. A., Bellio, M., Bocher, P., Buchanan, G. M., Clay, R. P., Conklin, J., Crockford N., Dann, P., Elts, J., Friis, Ch., Fuller, R. A., Gill, J. A., Gosbell, K., Johnson, J. A., Marquez-Ferrando, R., Masero, J. A., Melville, D. S., Millington, S., Minton, C., Mundkur, T., Nol, E., Pehlak, H., Piersma, Th., Robin, F., Rogers, D. I., Ruthrauff, D. R., Senner, N. R., Shah, J. N., Sheldon, R. D., Soloviev, S. A., Tomkovich, P. S., Verkuil, Y. I., 2017. A Global Threats Overview for Numeniini Populations: Synthesizing Expert Knowledge for a Group of Declining Migratory Birds, Bird Conservation International. 27, 1, 6-34.

Schuckard, R., Huettmann, F., Gosbell, K., Geale, J., Kendal, S., Gerasimov, Yu., Matsina, E., Greeves, W., 2006. Shorebird and Gull Census at Moroshechnaya Estuary, Kamchatka, Far East Russia, during August 2004, Stilt. 50, 34-46.

Studds, C. E., Kendall, B. E., Murray, N. J., Wilson, H. B., Rogers, D. I., Clemens, R. S., Gosbell, K., Hassell, C. J., Jessop, R., Melville, D. S., Milton, D. A., Minton, C. T. D., Possingham, H. P., Riegen, A. C., Straw, P., Woehler, E. J., Fuller, R. A., 2017. Rapid Population Decline in Migratory Shorebirds Relying on Yellow Sea Tidal Mudflats as Stopover Sites, Nature Communications. 8,14895. 